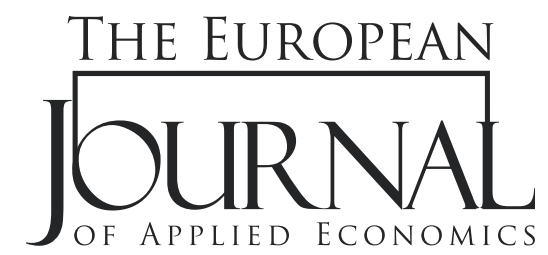

\title{
THE INFLUENCE OF SOCIODEMOGRAPHIC CHARACTERISTICS OF RESIDENTS ON THE PERCEPTION OF TOURISM DEVELOPMENT IMPACTS
}

Ilinka Stojković, Jelena Tepavčević*, Ivana Blešić, Milan Ivkov, Viktorija Šimon

Faculty of Natural Sciences,

Department of Geography, Tourism and Hospitality,

University of Novi Sad,

Serbia

\begin{abstract}
:
Residents play an important role in the process of destination development, but a supportive attitude in regard to tourism is key to the success of the touristic destination. Various authors have examined residents' attitudes towards the impacts of tourism development from different points of view. This paper aimed to investigate the impacts of sociodemographic characteristics of locals on their attitudes towards tourism development. The study was conducted on the territory of Sirinićka Župa, in the municipality of Štrpce. A total of 94 respondents were included in the research. The results indicated that gender and education level have not influenced residents' attitudes. On the other hand, it has been found that the age and length of residents' significantly influence residents' attitudes towards tourism development impacts.
\end{abstract}

Article info:

Received: May 30, 2020

Correction: July 31, 2020

Accepted: September 11, 2020

Keywords:

Sirinićka Župa,

residents,

tourism development,

tourism impacts,

sociodemographic characteristics.

\section{INTRODUCTION}

Local population is fundamental for the growth and success of touristic destinations, so it is important to follow a positive feeling towards the growth of tourism. The support for tourism development provided by residents can contribute to the tenacity and successful improvement of community in developing (Albu, 2020; Hai and Alamgir, 2017; Kihima and Musila, 2019) and developed countries (Castela, 2018; Rasoolimanesh et al., 2017). There is growing proof that residents of communities that attract visitors express heterogeneous views about their region`s growth (Mason and Cheyne, 2000) and their attitudes vary depending on the stage of development of the destination (Butler, 1980; Doxey, 1975). Throughout the years, residents have been exposed to tourism development effects (Brida et al., 2010) and these effects are clustered to show socio-cultural, economic, and environmental aspects of sustainable development of tourism (Andersson et al., 2016). Tourism development can negatively influence a local community 
due to the environmental and socio-cultural costs (Lo et al., 2014; Naidoo and Sharpley, 2015). On the other hand, the effects of investing in the local community are reduced departure of educated and young people, a reduction of poverty, higher employment, encouragement of opening of small and medium enterprises, etc. (Lyons, 2015).

An increasing number of research has dealt with different approaches of examination of the attitudes and perceptions of residents towards tourism development effects (Adongo et al., 2017; Cavus and Tanrisevdi, 2002; Eslami et al., 2019; Gursoy et al., 2018; Ouyang et al., 2017; Rasoolimanesh et al., 2017; Zhu et al., 2017). There are few studies on the impact of tourism either before any growth was not registered or when it has not yet considered to be a major economy (Hernandez et al., 1996). Researchers have also attempted to create links between specific local views and other facets of these populations, such as demographic influences, reliance on tourism, and closeness of residents to this growth. Although several studies have indicated that demographic factors are not correlated with local populations' attitudes in regard to tourism development (Cui and Ryan, 2011; Nunkoo and Ramkissoon, 2010), many studies have found a significant impact of sociodemographic characteristics on shaping residents' attitudes (Bagri and Kala, 2016; Cavus and Tanrisevdi, 2002; Jackson and Inbakaran, 2006; Mason and Cheyne, 2000; Snyman, 2014, Vareiro et al., 2013). Jackson and Inbakaran (2006) identified general characteristics of the destination residents, which are correlated with a positive attitude towards tourism growth. The results indicate that female residents are more supportive of tourism development. Residents who have completed higher education provide support for tourism development, they are employed and have a higher wage, they have a higher-ranking political role in society, work in the tourism sector, and live in an area which is urban (Jackson and Inbakaran, 2006). The authors also failed to determine any significant relationship between negative attitudes towards tourism and the demographics of residents. McGool and Martin (1994) examined the connection between the commitment of residents to their communities and their attitudes in regard to the effects of tourism growth. They determined that locals who have stronger attachments to the community have more hostile attitudes towards tourism growth in comparison to the local residents who have shown lower levels of attachment. Many studies suggest that, with the increase in the length of the period of living in the community, attitudes towards tourism growth become more negative (Khoshkam et al., 2016; Liu et al., 1987).

As a settlement in the foothill of the Šar mountain, Sirinićka Župa is just one of the inhabited places whose residents can experience the consequences of tourism development. In the last 20 years, the tourism development in this area stagnated due to the political situation in the area of Kosovo. Consequently, there were no official records of the number of tourist arrivals and overnights in this area in the Bureau of Statistics of the Republic of Serbia. According to internal data obtained from the Molika hotel (Hotel Molika, 2019), a significant increase was registered in the number of tourist arrivals in the last three years in comparison with the stagnation phase. This can be an indicator of the redevelopment of Šar mountain as a tourism destination which, according to the Butler's life cycle of evolution (Butler, 1980), can be considered as a beginning of the involvement development stage. The development stage is a significant factor that can influence the interaction between tourists and hosts (Butler, 1980). According to Doxey (1975), the interaction between hosts and tourists can be explained through four phases: euphoria, apathy, irritation, and antagonism. When considering the characteristics of each phase, as well as the fact that this area just recently started to develop its tourism again, the interaction phase between the locals and guests can be considered as euphoric. The local population perceive tourism as an opportunity for economic prosperity, and awaits its tourists with enthusiasm. Indications that tourism in this area has started to develop again has aroused interest for examining residents' perceptions towards the impacts of tourism development. 


\section{LITERATURE REVIEW}

Residents are an important part of the process of development and success of the destination. Various authors have investigated the views of locals regarding the effects of tourism growth from various viewpoints. By analyzing the studies about residents' perception towards tourism impact, many different models of examining residents' impact and perceptions can be identified. In many studies, there is an association between attitudes towards effects of tourism and sociodemographic characteristics such as gender (Mason and Cheyne, 2000; Nunkoo and Gursoy, 2012; Jani, 2018; Tepavčević et al., 2019; Janta and Christou, 2019; Alrwajfah et al., 2020, Wang, 2013), age (Bagri and Kala, 2016; Látková and Vogt, 2012; Sinclair-Maragh, 2017), nationality (Hernández and Mercader, 2015; Soontayatron; 2010), urban as well as rural areas (Rasoolimanesh et al., 2017), education levels (Miyakuni, 2012; Pavlić et al., 2019; Pham and Kayat, 2011), length of period of residence (Khoshkam et al., 2016; Liang and Hui, 2016; Xu et al., 2016), and family size (Brida et al., 2011).

\section{Impacts of Gender on Locals' Attitudes Towards Tourism Development}

Several studies have remarked that gender is a deciding element in the attitudes of locals towards the effects of tourism (Mason and Cheyne, 2000; Nunko and Gursoy, 2012). In the study conducted by Mason and Cheyne (2000), differences in the perceptions of gender-based tourism impacts have been identified, with male respondents being more positive than female respondents in terms of tourism development. Nunko and Gursoy (2012) have determined variations in attitudes in the sense that gender is a strong indicator of tourism support and negative impacts. They also indicated that the impact of gender on attitudes towards tourism development is not only influenced by biological differences characterized for the gender, but also by psychological differences between males and females (Nunko and Gursoy, 2012). In their work, Teparčević et al. (2019) found notable differences among male and female residents. Jani (2018) and Alrwajfah et al. (2020) determined a significant impact of gender on residents' perceptions toward tourism development. On the other hand, several studies have not identified any major gender effect on the understanding of the effects of tourism growth (Almeida-Garcia et al., 2016; Bagri and Kala, 2016; Mensah, 2012; Rasoolimanesh et al., 2015)

In respect of existing literature, the following hypotheses can be posed:

H1: Gender is an indicator of significant differences in locals' attitudes towards tourism growth effects.

\section{Impacts of Age on Locals' Attitudes Towards Tourism Development}

Látková and Vogt (2012) identified that older residents are more inclined to accept that tourism has more positive effects than negative, while younger residents are more likely to perceive the negative effects of tourism growth. In their study, Rasoolimanesh et al. (2015) have found that older residents are more positive towards tourism due to more benefits they can gain. Bagri and Kala (2016) examined residents in India, and found that older residents expressed fewer positive perceptions of development of tourism when compared to younger residents. Cavus and Tanrisevdi (2002) also found that elderly community members showed less support for tourism growth than younger ones. Almeida-García et al. (2016) identified the important main effects of the tourism destination residents' age on the perceptions of the environmental and economic impacts. They failed to find any significant effects of age on socio-cultural effects and overall attitudes of tourism development. Vareiro et al. (2013) reported a higher level of concern about the impacts of tourism, which are considered as negative among older residents compared to younger residents. 
Tepavčević et al. (2019) and Rasoolimanesh et al. (2015) also reported differences in prehension of tourism impacts towards the age of respondents, i.e., younger respondents have the lower perception of tourism impacts than older residents. Sinclair-Maragh (2017) identified that younger residents (18-25 years) tend to be more supportive towards tourism development than older residents.

In respect of existing literature, the following hypothesis can be posed:

H2: Age is an indicator of significant differences in local populations' attitudes towards tourism growth effects.

\section{Impacts of Education Level on Local Populations' Attitudes Towards Tourism Development}

Earlier studies have determined that degree of education is the most notable single element influencing residents' views on the travel industry. Education may improve the communication skills of community members, as well as their awareness levels concerning tourism-related issues (Sinclair-Maragh, 2017). Papastathopoulos et al. (2019) indicated on differences in perceptions of tourism development impacts depending on education level. They found that a higher education level of residents has a more powerful influence on the residents' perception of cultural, social, and environmental impacts. On the other hand, residents with lower education levels have a stronger perception toward the economic impacts of tourism development. Pham and Kayat (2011) indicated differences among residents, depending on their education level. They found that residents with lower education level are more critical of the effects of tourism development compared to highly educated residents, who are enthusiastic towards tourism development. Miyakuni (2012) determined that residents who possess a lower level of education show a more critical attitude towards the growth of tourism than higher-educated residents. In their study, Vareiro et al. (2013) found that tourism destination residents with a completed high school education expressed more expectations regarding the positive effects of tourism. However, they also expressed low concerns about the eventual negative impacts. Almeida-García et al. (2016) reported an important effect of the degree of education on the acceptance of the environmental, socio-cultural, and economic impacts. They found that as the education level of residents increases, the perception of the effects of tourism increases as well. Tepavčević et al. (2019) reported that highly educated residents have a higher perception of all kinds of tourism impacts. They found that residents with the lowest education level have the lowest perception of all tourism effects, and their support for tourism growth is low.

In respect of existing literature, the following hypothesis can be posed:

H3: Level of education is an indicator of significant differences in locals' attitudes towards tourism growth effects.

\section{Impacts of the Length of Period of Residence on Local Populations' Attitudes Towards Tourism Development}

Khoshkam et al. (2016) found different relationships between the length of period of residence and perceptions of tourism development effects. For example, they found that the time length of residence positively influences perceptions of economic impacts, while there is a negative relationship between the length of time of residence and perceptions of socio-cultural impacts. The authors found no significant relationship between the perceptions of impacts on the environment and the length of time of residence. Liang and Hui (2016) found that residential status significantly influences residents' support for development of tourism. 
They also found that homeowners have a more positive attitude towards tourism development compared to tenants and dormitory residents. These findings supported the findings of several studies (Liu et al., 1987). Pham and Kayat (2011) found that the length of time of residence has a limited influence on residents' perceptions and support for tourism development. On the other hand, Papasrathopoulos et al. (2019) and Bhat and Mishra (2020) failed to identify significant effects of length of period of residence on the perceptions of tourism development impacts. In addition, Sinclair-Maragh (2017) did not find any significant impact of length of time of residence towards their support for tourism development.

In respect of existing literature, the following hypothesis can be posed:

H4: The length of period of residence is an indicator of significant differences in locals' attitudes towards tourism growth effects.

\section{METHODOLOGY}

This research focused on the perception of the residents of Sirinićka Župa (Štrpce Municipality) of the effects of tourism growth (environmental, economic, socio-cultural, and physical impacts) according to their sociodemographic characteristics (gender, age, education level, and length of time of their residence). The survey, composed of two section,s was used for research purposes. The first segment of the survey consisted of questions related to the sociodemographic characteristics of the respondents, including their age, degree of education, the status of their employment, the level of their incomes, and the relatedness of their work with tourism. One question was related to the length of residency in Sirinićka Župa.

The second segment of the survey consisted of items designed to measure the attitudes of locals about the effects of tourism development. In this study, the model of Muresan et al. (2016) was used. The model includes 22 items, disposed to 4 factors. The first factor (Environmental impact) included 8 items designed for measuring the perception of the residents toward environmental impacts. The items were related to problems of pollution, overcrowding, and other effects of tourism growth on the environment which are considered negative (e.g., "Development of tourism can damage the natural environment and landscape"). The second factor (Economic impacts) included 7 items associated with the economic advantages of tourism development (e.g., "Tourism creates new jobs for locals"). The third factor (Social and Cultural impacts) consisted of 4 items which were associated to be the positive effects of tourism growth on society, as well as on culture (e.g." "Tourism provides incentives for the restoration of traditional houses"). The last, fourth factor (Physical impacts) had 3 items, which were related to the perception of the improvement of the infrastructure on the local community (e.g., "Tourism can improve the living utility infrastructure (for example, water supply, sewage, the electric supply, etc.)"). A Likert scale ranging from 1 (definitely disagree) to 5 (definitely agree) was used for expressing the level of agreement offered. The research was conducted from August 2019 to January 2020 on the territory of Sirinićka Župa. Some of the respondents were surveyed online, while the rest were interviewed using the face-to-face technique. A total of 94 respondents were included in the research. All the collected surveys were valid. 


\section{RESULTS}

\section{Sample Description}

The first segment of the survey was related to the socio-demographic characteristics of respondents. The socio-demographic characteristics of residents are presented in Table 1. Considering gender structure, more than half of the sample consists of male respondents (53.2\%), while the female ones participated with $46.8 \%$. When observing the age structure of respondents, it is visible that respondents from the age group "up to 24 " (33\%) and "25-34" (26.6\%) constitute the largest part of the sample. Respondents from the age group "over 55 " participated with only 9.6\%. Most respondents had completed high school (47.9\%), followed by respondents who graduated (19.1\%). The permanently employed (35.1\%) made up a third of the sample, while the lowest percentage of respondents (3.2\%) were retired. If we observe the level of income of respondents, it is visible that just over one-third of the sample (35.1\%) earns up to $200 €$, followed by respondents with the level income between 201 and $500 €(31.9 \%)$. Only $4.3 \%$ of the respondents have reported a level of incomes over $1001 €$.

Table 1 Socio-demographic Characteristics of Respondents

\begin{tabular}{|c|c|c|}
\hline Socio-demographic characteristics & Frequency & Percent \\
\hline \multicolumn{3}{|c|}{ Gender } \\
\hline Male & 50 & 53.2 \\
\hline Female & 44 & 46.8 \\
\hline \multicolumn{3}{|c|}{ Age } \\
\hline Up to 24 & 31 & 33.0 \\
\hline $25-34$ & 25 & 26.6 \\
\hline $35-46$ & 19 & 20.2 \\
\hline $47-54$ & 10 & 10.6 \\
\hline Over 55 & 9 & 9.6 \\
\hline \multicolumn{3}{|c|}{ Education } \\
\hline High school & 45 & 47.9 \\
\hline College & 15 & 16.0 \\
\hline Graduate & 18 & 19.1 \\
\hline Master & 16 & 17.0 \\
\hline \multicolumn{3}{|c|}{ Employment status } \\
\hline Pupil/Student & 26 & 27.7 \\
\hline Permanently employed & 33 & 35.1 \\
\hline Temporarily employed & 16 & 17.0 \\
\hline Retired & 3 & 3.2 \\
\hline Unemployed & 16 & 17.0 \\
\hline \multicolumn{3}{|c|}{ Income level } \\
\hline Up to $200 €$ & 33 & 35.1 \\
\hline $201-500 €$ & 30 & 31.9 \\
\hline $501-1000 €$ & 27 & 28.7 \\
\hline More than $1001 €$ & 4 & 4.3 \\
\hline
\end{tabular}

Source: Authors' research 
Table 2 presents the results of descriptive statistical analysis. The results indicated that the lowest value was registered for the factor Environmental impacts (2.83), while the factor Social and Cultural Impacts has the highest value (4.13). The item valued the lowest by the residents is "Tourism development negatively affects the recreational facilities and entertainment" (2.06), while the item which was valued the highest is "Tourism plays an important role in the economic development of the area" (4.40). According to Doxey (1975), the negative impacts of tourism occur when development is not well planned or managed properly. If we look at the stage of the development of the area (involvement stage), it is quite expected that the impacts on the environment will be less perceived and not considered as negative. An increase of tourist turnover (arrivals and overnights), as well as the change of the development stage of the area, can result in changes in attitudes and perceptions of local residents towards the impacts of tourism development.

Table 2 Descriptive Statistical Analysis

\begin{tabular}{|c|c|c|}
\hline Factors & Mean & $\begin{array}{l}\text { Std. } \\
\text { Deviation }\end{array}$ \\
\hline Environmental Impacts & 2.83 & 0.838 \\
\hline Development of tourism damages the natural environment and landscape. & 2.91 & 1.389 \\
\hline Tourism causes overcrowding problems for residents. & 2.66 & 1.258 \\
\hline Tourism increases air pollution. & 2.81 & 1.314 \\
\hline Tourists use too much water. & 2.73 & 1.099 \\
\hline Tourism results in more litter in the area. & 3.29 & 1.151 \\
\hline Tourism development negatively affects the recreational facilities and entertainment. & 2.06 & 1.105 \\
\hline The construction of tourist facilities destroys the environment. & 2.49 & 1.034 \\
\hline Increase in traffic problems. & 3.69 & 0.951 \\
\hline Economic Impacts & 3.89 & 0.536 \\
\hline Tourism plays an important role in the economic development of the area. & 4.40 & 0.780 \\
\hline Tourism improves locals' living standard. & 4.30 & 0.814 \\
\hline Tourism increases a community`s tax revenue. & 4.00 & 1.097 \\
\hline Tourism creates new jobs for locals. & 4.28 & 0.860 \\
\hline Tourism diversifies the rural economy. & 3.18 & 1.037 \\
\hline Tourism results in an increase in living costs. & 2.85 & 1.235 \\
\hline $\begin{array}{l}\text { Revenue from tourism tax activity should be invested in the future development } \\
\text { of tourism. }\end{array}$ & 4.21 & 0.866 \\
\hline Social and Cultural Impacts & 4.13 & 0.638 \\
\hline Tourism provides incentives for the restoration of traditional houses. & 4.07 & 0.858 \\
\hline Interaction with tourists is a positive experience. & 4.28 & 0.694 \\
\hline Shopping and restaurant options are better as a result of tourism. & 4.00 & 0.892 \\
\hline Tourism development enhances more recreational opportunities for locals. & 4.17 & 0.785 \\
\hline Physical Impacts & 3.88 & 0.776 \\
\hline Improvement in traffic network. & 4.06 & 0.878 \\
\hline Improvement in living utilities infrastructure (supply of water, sewage, electric, etc.) & 3.76 & 1.002 \\
\hline Quality of public services is better. & 3.81 & 0.919 \\
\hline
\end{tabular}




\section{Results of T-test}

T-test of independent samples according to gender (Table 3 ) indicated that there are no important differences among males and females regarding the understanding of the various effects of tourism growth. Obtained results did not provide support for $\mathrm{H} 1$.

Table 3 T-test According to Gender

\begin{tabular}{|c|c|c|c|c|}
\hline \multirow{3}{*}{ Factors } & \multicolumn{2}{|c|}{ Gender } & \multirow{3}{*}{$\mathbf{t}$} & \multirow{3}{*}{$\mathbf{p}$} \\
\hline & Male & Female & & \\
\hline & $\mathrm{N}=50$ & $\mathrm{~N}=44$ & & \\
\hline Environmental Impacts & 3.86 & 3.89 & -.845 & .401. \\
\hline Economic Impacts & 2.76 & 2.91 & .264 & .792 \\
\hline Social and Cultural Impacts & 3.90 & 3.87 & .075 & .940 \\
\hline Physical Impacts & 4.14 & 4.13 & -.211 & .834 \\
\hline
\end{tabular}

Source: Authors' research

\section{Results of one-way ANOVA}

One-way ANOVA by age of respondents (Table 4) was applied with the aim of confirming H2. The results indicated that statistically significant differences exist within the factors Environmental Impacts $(\mathrm{p}<0.05, \mathrm{~F}=2.395)$ and Physical Impacts $(\mathrm{p}<0.05, \mathrm{~F}=2.611)$. By using LSD post-hoc test, it has been determined among which groups do notable differences exist. It can be noticed that respondents from the age group " 45 - 54" years express a significantly lower perception of tourism impact on the environment than the respondents from the age groups " $15-24$ " and " $25-34$ ". Within the factor Physical Impacts, respondents from the age group "15-24" expressed a significantly lower perception of Physical impacts of tourism development than respondents from groups " 45 - 54" and "55 - 64" years. These results support $\mathrm{H} 2$ partially.

Table 4 ANOVA by Age

\begin{tabular}{|c|c|c|c|c|c|c|c|c|}
\hline \multirow[b]{2}{*}{ Factors } & \multicolumn{5}{|c|}{ Age } & \multirow[b]{2}{*}{$\mathbf{F}$} & \multirow[b]{2}{*}{$\mathbf{p}$} & \multirow[b]{2}{*}{$\begin{array}{c}\text { LSD } \\
\text { post- } \\
\text { hoc }\end{array}$} \\
\hline & $\begin{array}{c}\mathbb{Z} \\
1 \\
10 \\
n\end{array}$ & $\begin{array}{c}\text { m } \\
1 \\
\stackrel{n}{n}\end{array}$ & \begin{tabular}{c}
\multirow{H}{*}{} \\
1 \\
$n$ \\
$n$
\end{tabular} & $\begin{array}{l}4 \\
1 \\
1 \\
\text { L }\end{array}$ & $\begin{array}{l}\text { t } \\
1 \\
\text { in }\end{array}$ & & & \\
\hline Environmental Impacts & 3.09 & 2.89 & 2.74 & 2.24 & 2.61 & 2.395 & .050 & $4<1,2$ \\
\hline Economic Impacts & 3.88 & 3.86 & 3.78 & 4.09 & 4.06 & .661 & .621 & - \\
\hline Social and Cultural Impacts & 4.17 & 4.05 & 3.97 & 4.45 & 4.19 & 1.068 & .377 & - \\
\hline Physical Impacts & 3.67 & 4.00 & 3.65 & 4.23 & 4.33 & 2.611 & .041 & $1<4,5$ \\
\hline
\end{tabular}

Taking the level of education as a variable for applying one-way ANOVA (Table 5), it has been determined that the degree of education of residents does not influence the perception of tourism development. Hence, H3 is not supported. 
Table 5 ANOVA by education level

\begin{tabular}{|c|c|c|c|c|c|c|c|}
\hline \multirow[b]{2}{*}{ Factors } & \multicolumn{4}{|c|}{ Education level } & \multirow[b]{2}{*}{$\mathbf{F}$} & \multirow[b]{2}{*}{$\mathbf{p}$} & \multirow[b]{2}{*}{$\begin{array}{c}\text { LSD } \\
\text { post-hoc }\end{array}$} \\
\hline & 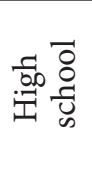 & $\frac{\mathscr{8}}{\stackrel{0}{0}}$ & 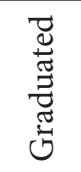 & $\frac{\dot{ \pm}}{\stackrel{\Xi}{\Xi}}$ & & & \\
\hline Environmental Impacts & 2.89 & 2.87 & 2.85 & 2.59 & .518 & .671 & - \\
\hline Economic Impacts & 3.85 & 3.84 & 4.02 & 3.91 & .470 & .704 & - \\
\hline Social and Cultural Impacts & 4.07 & 4.12 & 4.33 & 4.08 & .764 & .517 & - \\
\hline Physical Impacts & 3.86 & 3.93 & 3.98 & 3.75 & .279 & .840 & - \\
\hline
\end{tabular}

Source: Authors' research

In the case of length of time of residence, one-way ANOVA found significant differences $(\mathrm{p}<0.5, \mathrm{~F}=3.606)$ within the factor Environmental Impacts (Table 6). By applying a LSD post-hoc test, it has been determined that residents who have been living in Sirinićka Župa for less time (10 - 15 years) have a stronger perception of the effects of tourism on the local environment than those who have been living there longer (over 15 years), as well as those who were born in Sirinić Župa but currently have another place of residence. Based on the previously presented results, $\mathrm{H} 4$ is partly supported.

Table 6 ANOVA by the Length of Time of Residence

\begin{tabular}{|c|c|c|c|c|c|c|}
\hline \multirow[b]{2}{*}{ Factors } & \multicolumn{3}{|c|}{ Education level } & \multirow[b]{2}{*}{$\mathbf{F}$} & \multirow[b]{2}{*}{$\mathbf{p}$} & \multirow[b]{2}{*}{$\begin{array}{c}\text { LSD } \\
\text { post-hoc }\end{array}$} \\
\hline & \begin{tabular}{c}
$\infty$ \\
\multirow{J}{*}{} \\
$\stackrel{\infty}{2}$ \\
10 \\
1 \\
0 \\
0
\end{tabular} & 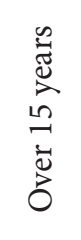 & 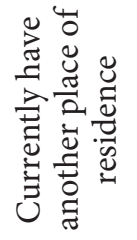 & & & \\
\hline Environmental Impacts & 3.51 & 2.79 & 2.70 & 3.606 & .031 & $1>2,3$ \\
\hline Economic Impacts & 3.87 & 3.83 & 4.00 & .964 & .385 & - \\
\hline Social and Cultural Impacts & 3.77 & 4.11 & 4.28 & 2.234 & .113 & - \\
\hline Physical Impacts & 4.11 & 3.78 & 3.98 & 1.078 & .345 & - \\
\hline
\end{tabular}

$* \mathrm{p}<0.5$

Source: Authors' research

\section{ACKNOWLEDGEMENTS:}

The represented research is part of project 176020 OI, funded by the Ministry of Education, Science and Technological Development of the Republic of Serbia. 


\section{CONCLUSION}

Recognizing the pertinence of the role of the locals in the tourist destination growth, it is crucial to investigate their attitudes towards tourism development. Tourism development brings several impacts on the local community, positive, as well as the negative ones, depending on the stage of development of a destination. Although residents perceive the Social and Cultural impact the most, depending on the stage of development and the phase of interaction between residents and tourists, it can be considered both positive and negative. In this case, it can be considered as positive due to the fact that uncontrolled tourism development has still yet to occur, which can influence the space transformation, and quality of local population life (Fachrudin and Lubis, 2016; Andereck and Nyaupane, 2011; Elliot et al., 2011).

In this study, residents expressed the lowest perception of environmental impact while perceiving the socio-cultural impacts the most. This could be explained by the phase in the life cycle of a tourist destination. Because of the political situation in the country, in the earlier years, tourism development in this area was stagnant. However, an increase of the number of ski tourists in Sirinićka Župa has been registered in the last few years. Besides locals and domestic tourists, a significant number of foreign tourists was registered during the winter season. Furthermore, besides skiers, tourists often visit only to walk and they do not use the ski slopes. Moreover, in line with the increase of ski tourists, an increase in the number of weekend cottages on the way to the ski center was registered in the last five years. Because of their location, weekend cottages are generally the first choice of ski tourists. The Organization "Serbia for Youth" greatly promotes tourism in this area by organizing multi-day stays for young people. All previously mentioned points are good indicators of the beginning of tourism development in Sirinićka Župa and on Šar Mountain. The focus of this study was to determine the effects of socio-demographic characteristics of the local population on attitudes towards tourism development. Referring to the results obtained in this study, it can be concluded that the residents' socio-demographic characteristics influence their attitudes towards tourism growth. Firstly, contrary to expectations, the gender of residents was not found as evidence of disparities in the residents ' perceptions towards tourism effects. Although numerous authors indicated the impact of gender on residents' attitudes (Mason and Cheyne, 2000; Nunko and Gursoy, 2012; Tepavčević et al., 2019), the findings of this research are consistent with the results obtained in the Almeida-García et al. (2016) study, which did not find any significant relationship between gender and residents' attitudes. These results have not provided support for H1. Secondly, in many studies, age is considered a significant determinant of differences in the perception of tourism impacts (Cavus and Tanrisevdi, 2002). Significant effects of age were found in the residents' attitudes towards Environmental Impacts and Physical Impacts. In the case of perception of environmental impacts, older residents expressed lower perception of tourism impacts than younger ones. Considering the differences in the perception of physical impacts, the youngest residents (age group 15-24) have lower prehension of physical effects of tourism development than older residents (age groups 45-54 and 55-64). Based on this, H2 is supported partially. Furthermore, many authors found significant effects of education level on residents' attitudes (Pham and Kayat, 2011; Vareiro et al., 2013). Results of this study have not found a notable link between the degree of education and perceptions towards tourism effects. Thus, $\mathrm{H} 3$ is not supported. Finally, the length of time of residence was the last variable whose impact on attitudes was examined. Previous studies have confirmed the influence of the length of residence on local population attitudes (Cavus and Tanrisevdi, 2002; Liu et al., 1987). In this study, the notable correlation between the period of residence and the local population's attitudes was found in the perception of tourism effects on the environment. Based on this, H4 is partially supported. 
Taking into consideration the significance of the human factor in achieving success in a sector such as tourism, the results of this study can enable better insight into the attitudes of the local residents for tourism development planners. It is mandatory to include the local population in all aspects of tourism development-economic, political and socio-cultural ones. Through the identification of factors which can influence the attitudes and support for tourism development, various strategies can be formed, which would include local population and through which they would stimulate them to get involved more actively in the tourism related activities. Considering that this area is in its redevelopment stage, local production could be stimulated with a goal of creating recognizable products with the help of the local population. In this way, local products could be branded, and the economic benefits for the local population would be observed.

Finally, this research has several limitations, which provide opportunities for further future examination. First of all, the number of respondents included in the research is small. Although the period of data collection lasted several months, the greatest problem was the lack of interest of residents to fill out the survey. The period during which the interviewer stayed in the researched area was very brief, and a small number of residents was surveyed, due to which a combination of online and face-to-face techniques was used for gathering the data. With the use of the online survey, the response of younger residents was higher, and hence the higher share of younger population in the sample. Due to the fact that the research was conducted only in Sirinićka Župa, and that in the Štrpce Municipality there are few villages that are in the very vicinity of the ski centers (Brezovica, Vrbeštica, Sevce, Jažince, Štrpce, Berevce, Popovce, Bitinja), the acquired results cannot be generalized, but they relate just on the perception of the influence of tourism development of residents of Sirinićka Župa. Due to this reason, the recommendation for future research is to expand it on all villages in the municipality in order to obtain conclusions on the attitudes and perceptions of residents of the entire area concerning the influence of tourism development. Secondly, previous research has shown that locals who profit from tourism have more positive attitudes towards the effects of tourism (Milman and Pizam, 1988). Due to the stagnation period in development of a tourist destination caused by the political situation, it is obvious that residents were not financially dependent on tourism development, which is why financial dependence on tourism development was not observed. Therefore, depending on the future development of the destination, it is a recommendation for future research to consider financial dependence on tourism growth as a variable to discover whether there are differences in attitudes. Taking into account that residents' attitudes change over time and vary depending on the stage of tourism development of the touristic destination, further research should be focused on repeating this study at another stage of development.

\section{REFERENCES}

Adongo, R., Choe, J. Y., \& Han, H. (2017). Tourism in Hoi An, Vietnam: impacts, perceived benefits, community attachment and support for tourism development. International Journal of Tourism Sciences, 17(2), 86-106. doi.org/10.1080/15980634.2017.1294344

Albu, R. (2020). Study on the effects of tourism development on the local community of Brasov. Bulletin of the Transilvania University of Brasov. Series V: Economic Sciences, 12(2), 37-42. doi.org/10.31926/but.es.2019.12.61.2.5

Almeida-García, F., Peláez-Fernández, M. Á., Balbuena-Vázquez, A., \& Cortés-Macias, R. (2016). Residents' perceptions of tourism development in Benalmádena (Spain). Tourism Management. 54, 259-274. doi.org/10.1016/j.tourman.2015.11.007 
Alrwajfah, M. M., Almeida-García, F., \& Cortés-Macías, R. (2020). Females' perspectives on tourism's impact and their employment in the sector: The case of Petra, Jordan. Tourism Management. 78. doi.org/10.1016/j.tourman.2019.104069

Andereck, K.L., \& Nyaupane, G.P. (2011). Exploring the Nature of Tourism and Quality of Life Perceptions among Residents. Journal of Travel Research, 50(3), 248-260.

Andersson, T.D., Armbrecht, J., \& Lundberg, E. (2016). Triple impact assessments of the 2013 European athletics indoor championship in Gothenburg. Scandinavian Journal of Hospitality and Tourism, 16(2), 158-179. doi.org/10.1080/15022250.2015.1108863

Bagri, S.C., \& Kala, D. (2016). Residents' attitudes toward tourism development and impacts in Koti-Kanasar, Indroli, Pattyur tourism circuit of Uttarakhand state, India. PASOS Revista de Turismo y Partrimonia Cultural, 14(1), 23-39. doi.org/10.25145/j.pasos.2016.14.002

Bhat, A.A., \& Mishra, R.K. (2020). Demographic characteristics and residents' attitude towards tourism development: A case of Kashmir region. Journal of Public Affairs. e2179. https://doi.org/10.1002/pa.2179

Brida, J.G., Osti, L., \& Barquet, A. (2010). Segmenting resident perceptions towards tourism-a cluster analysis with multinominal logit model of a mountain community. International Journal of Tourism Research, 12, 591-602. doi.org/10.1002/jtr.778

Brida, J.G., Osti., L., \& Faccioli, M. (2011). Residents' perception and attitudes towards tourism impacts: a case study of the small rural community of Folgaria (Trentino - Italy). Benchmarking: An International Journal, 18(3), 359-385. doi.org/10.1108/14635771111137769

Butler, R. (1980). The concept of tourism area cycle of evolution. Canadian Geographer, 24, 5-12.

Castela, A. (2018). Impacts of tourism in an urban community: The case of Alafama. Athens Journal of Tourism, 5(2), 133-148. https://doi.org/10.30958/ajt.5-2-4

Cavus, S., \& Tanrisevdi, A. (2002). Residents' attitudes Toward Tourism Development: A Case Study In Kusadasi, Turkey. Tourism Analysis. 7(3-4), 259-269. doi.org/10.3727/108354203108750102

Cui, X., \& Ryan, C. (2011). Perceptions of place, modernity and the impacts of tourism - differences among rural and urban residents of Ankang, China: a likelihood ratio analysis. Tourism Management, 32(3), 604-615. doi.org/10.1016/j.tourman.2010.05.012

Doxey, J. (1975). Development of Tourism Destinations. London:Torbay

Elliot, S., Papadopoulos., N., \& Kim, S.S. (2011). An Integrative Model of Place Image: Exploring Relationships between Destination, Product and Country Images. Journal of Travel Research, 50(5), 520-534. doi.org/10.1177/0047287510379161

Eslami, S., Khalifah, Z., Mardani, A., Streimikiene, D., \& Han, H. (2019). Community attachment, tourism impacts, quality of life and residents' support for sustainable tourism development. Journal of Travel \& Tourism Marketing, 36(9), 1061-1079. doi.org/10.1080/10548408.2019.1689224

Fachrudin, H. T., \& Lubis, M. D. (2016). Planning for riverside area as water tourism destination to improve quality of life local residents, case study: Batuan-Sikambing River, Medan, Indonesia. Procedia-Social and Behavioral Sciences, 234(31), 434-441. doi: 10.1016/j.sbspro.2016.10.261

Gursoy, D., Ouyang, Z., Nunkoo, R., \& Wei, W. (2018). Residents' impact perceptions of and attitudes towards tourism development: a meta-analysis. Journal of Hospitality Marketing \& Management, 28(3), 306-333. doi.org/10.1080/19368623.2018.1516589

Hai, A., \& Alamgir, B. (2017). Local community attitude and support towards tourism development at Saint Martin island, Bangladesh: Local community attitude and support. International Journal of Tourism and Hospitality Management in the Digital Age, 1(2), 32-41. doi: 10.4018/IJTHMDA.2017070103

Hernández, F. A. L., \& Mercader, S. D. L. S. T. (2015). Perceived Impact of Tourism by the Resident Population in Torrevieja: National versus Non-National Residents. European Journal of Tourism Research. 10, 120-26.

Hernandez, S.A., Cohen, J., \& Garcia, H.L. (1996). Residents`Attitudes Towards An Instant Resort Enclave. Annals of Tourism Research, 23, 755-779. doi.org/10.1016/0160-7383(95)00114-X 
Jackson, M. S., \& Inbakaran, R. J. (2006). Evaluating residents' attitudes and intentions to act towards tourism development in regional Victoria, Australia. International Journal of Tourism Research. 8(5), 355-366. doi.org/10.1002/jtr.584

Jani, D. (2018). Residents' Perception of Tourism Impacts and Involvement: A Cluster Analysis Of Kilimanjaro Residents, Tanzania. Business Management Review. 20(2), 60-71.

Janta, H., \& Christou, A. (2019). Hosting as social practice: Gendered insights into contemporary tourism mobilities. Annals of Tourism Research. 74, 167-176. doi.org/10.1016/j.annals.2018.11.008

Khoshkam, M., Marzuki, A., \& Al-Mulali, U. (2016). Socio-demographic effects on Anzali wetland tourism development. Tourism Management, 54, 96-106. https://doi.org/10.1016/j.tourman.2015.10.012

Kihima, B., \& Musila, P. (2019). Extent of local community participation in tourism development in conservation areas: A case study of Mwaluganje conservancy. Parks, 25(2), 47-56.

Látková, P., \& Vogt, C. (2012). Residents' Attitudes toward Existing and Future Tourism Development in Rural Communities. Journal of Travel Research, 51(1), 50-67. doi.org/10.1177/0047287510394193

Liang, Z.X., \& Hui, T.K. (2016). Residents' quality of life and attitudes toward tourism development in China. Tourism Management, 57, 56-67. doi:10.1016/j.tourman.2016.05.001

Liu, J. C., Sheldon, P. J., \& Var, T. (1987). Resident perceptions of the environmental impacts of tourism. Annals of Tourism Research. 14, 17-37. doi.org/10.1016/0160-7383(87)90045-4

Lo, M.C., Ramayah, T., \& Hui, H.L.H. (2014). Rural Communities Perceptions and Attitudes towards Environment Tourism Development. Journal of Sustainable Development, 7, 84-94. dx.doi.org/10.5539/jsd.v7n4p84

Lyons, T. S. (2015). Entrepreneurship and community development: what matters and why. Community Development. 46(5), 456-460. doi.org/10.1080/15575330.2015.1085194

Mason, P., \& Cheyne, J. (2000). Residents' attitudes to proposed tourism development. Annals of Tourism Research, 27(2), 391-411. https://doi.org/10.1016/S0160-7383(99)00084-5

McCool, S., \& Martin, S. 1994. Community attachment and attitudes toward tourism development. Journal of Travel Research, 32 (3), 29 -34 doi.org/10.1177/004728759403200305

Mensah, C. (2012). Residents' Perception of Socio-economic Impacts of Tourism in Tafi Atome, Ghana. Asian Social Science, 8(15), 274-287. doi:10.5539/ass.v8n15p274

Miyakuni, K. (2012). Residents' Attitudes toward Tourism, Focusing on Ecocecentric Attitudes and Perceptions of Economic Costs: The Case of Iriomote Island, Japan. PhD Thesis, Michigan State University.

Milman, A., \& Pizam, A. (1988). Social Impacts of Tourism on Central Florida. Annals of Tourism Research. 1(2), 191-204. doi.org/10.1016/0160-7383(88)90082-5

Muresan, I., Oroian, C., Harun, R., Arion, F., Porutiu, A., Chiciudean, G., \& Lile, R. (2016). Local residents' attitude toward sustainable rural tourism development. Sustainability. 8(1), 100. doi.org/10.3390/su8010100

Naidoo, P., \& Sharpley, R. (2015). Local perceptions of the relative contributions of enclave tourism and agritourism to community wellbeing: The case of Mauritius. Journal of Destination Marketing \& Management, 5, 16-25. https://doi.org/10.1016/j.jdmm.2015.11.002

Nunkoo, R., \& Gursoy, D. (2012). Residents' support for tourism: An identity perspective. Annals of Tourism Research. 39(1), 243-268. doi.org/10.1016/j.annals.2011.05.006

Nunkoo, R., \& Ramkisson, H. (2010). Small island urban tourism: a residents' perspective. Current Issues in Tourism, 13(1), 37-60. doi.org/10.1080/13683500802499414

Ouyang, Z., Gursoy, D., \& Sharma, B. (2017). Role of trust, emotions and event attachment on residents' attitudes toward tourism. Tourism Management, 63, 426-438. doi.org/10.1016/j.tourman.2017.06.026

Papastathopoulos, A., Ahmad, S. Z., Al Sabri, N., \& Kaminakis, K. (2019). Demographic Analysis of Residents' Support for Tourism Development in the UAE: A Bayesian Structural Equation Modeling Multigroup Approach. Journal of Travel Research, 59(6), 1119-1139. doi.org/10.1177/0047287519874131 
Pavlić, I., Puh, B., \& Mišković, L. (2019). Residents' Attitudes Towards Tourism Impacts In Rural Area. In Tourism in South East Europe: Creating Innovative Tourism Experiences - The Way to Extend the Tourist Season, 16-18 May, 2019, (pp. 521-532), Faculty of Tourism and Hospitality Management, Opatija. doi.org/10.20867/tosee.05.19

Pham, H.L., \& Kayat, K. (2011). Residents' perceptions of tourism impact and their support for tourism development: the case study of Cuc Phuong National Park, Ninh Binh province, Vietnam, European Journal of Tourism Research, 4(2), 123-164.

Rasoolimanesh, S. M., Jaafar, M., Kock, N., \& Ramayah, T. (2015). A Revised Framework of Social Exchange Theory to Investigate the Factors Influencing Residents' Perceptions. Tourism Management Perspective. 16, 335-345. https://doi.org/10.1016/j.tmp.2015.10.001

Rasoolimanesh, S. M., Ringle, C. M., Jaafar, M., \& Ramayah, T. (2017). Urban vs. rural destinations: Residents' perceptions, community participation and support for tourism development. Tourism Management. 60, 147-158. https://doi.org/10.1016/j.tourman.2016.11.019

Sinclair-Maragh, G. (2017). Demographic Analysis of Residents' Support for Tourism Development in Jamaica. Journal of Destination Marketing \& Management. 6(1), 5-12. doi.org/10.1016/j.jdmm.2016.03.005

Snyman, S. (2014). Assessment of the main factors impacting community members' attitudes towards tourism and protected areas in six southern African countries. Koedoe, 56(2), 1-12.

Soontayatron, S. (2010). Socio-cultural Changes in Thai Beach Resorts : A Case Study of Koh Samui Island, Thailand. PhD thesis, Bournemouth University.

Tepavčević, J., Blešić, I., Bradić, M., \& Ivkov, M. (2019). Attitudes of local residents towards tourism development in Vrbas. TIMS. Acta. 13(1), 15-25. doi: 10.5937/timsact13-18166

Vareiro, L. M. D. C., Remoaldo, P. C., \& Cadima Ribeiro, J. A. (2013). Residents' perceptions of tourism impacts in Guimarães (Portugal): A cluster analysis. Current Issues in Tourism, 16(6), 535-551. doi.org/10.1080/13683500.2012.707175

Wang, S. (2013). Predicting Effects of Demographics and Moderating Power of Engagement on Residents' Perceptions of Tourism Development. European Journal of Tourism Research, 6(2), 170-182.

Xu, S., Barbieri, C., Anderson, D., Leung, Y.-F., \& Rozier-Rich, S. (2016). Residents' perceptions of wine tourism development. Tourism Management, 55, 276-286. doi:10.1016/j.tourman.2016.02.016

Zhu, H., Liu, J., Wei, Z., Li, W., \& Wang, L. (2017). Residents' attitudes towards sustainable tourism development in a historical-cultural village: Influence of perceived impacts, sense of place and tourism development potential. Sustainability, 9(1), 61. doi.org/10.3390/su9010061 


\section{UTICAJ SOCIODEMOGRAFSKIH KARAKTERISTIKA REZIDENATA NA}

\section{PERCEPCIJU UTICAJA RAZVOJA TURIZMA}

\section{Rezime:}

Lokalno stanovništvo ima značajnu ulogu u procesu razvoja destinacije, a njihova podrška je ključna za uspeh destinacije. Brojni autori su istraživali stavove lokalnog stanovništa prema turističkim uticajima sa različitih stanovništa. Cilj ovog rada je bio istraživanje uticaja sociodemografskih karakteristika lokalnog stanovništva na njihove stavove prema razvoju turizma. Istraživanje je sprovedeno na teritoriji Sirinićke Župe, u okviru opštine Štrpce. U istraživanju je učestvovalo ukupno 94 rezidenata. Rezultati su pokazali da pol i nivo obrazovanja nemaju značajan uticaj na stavove lokalnog stanovništa. Sa druge strane, starosna dob i dužina borakva u Sirinićkoj Župi su pokazale značajan uticaj na stavove lokalnog stanovništva prema uticajima razvoja turizma.

\section{Ključne reči:}

Sirinićka Župa,

lokalno stanovništvo, razvoj turizma, uticaj turizma, sociodemografske karakteristike. 